\title{
THE IMPACT OF INSTITUTIONAL PERFORMANCE ON PAYMENT DYNAMICS: EVIDENCE FROM THE ITALIAN MANUFACTURING INDUSTRY
}

\author{
Greta FALAVIGNA ${ }^{(1)}$, Roberto IPPOLITIII $2^{*}$ \\ ${ }^{1}$ Research Institute on Sustainable Economic Growth, CNR, Moncalieri, Italy \\ ${ }^{2}$ Faculty of Business Administration and Economics, Bielefeld University, Bielefeld, Germany
}

Received 03 January 2020; accepted 03 June 2020

\begin{abstract}
This work aims to shed new light on the relation between institutional performance and firm dynamics. Considering the Italian manufacturing industry and a panel of 3 years, the authors investigate the relation between the time needed by courts to enforce debtors' obligations and the time needed by enterprises to repay their debts. In particular, we test the hypothesis that efficiency in settling mortgage foreclosure and bankruptcy cases can affect the creditors' decision making on judicial disputes. According to our thesis, inordinately long waiting times to enforce credit rights may increase the contractual strength of debtors, further delaying payments. As shown by our results, there is a statistically significant positive relation between the enforcement of debtors' obligations and the adopted payment index, confirming the key role of the judiciary in the dynamics of firms. Indeed, if the time needed to settle bankruptcy cases decreases by $25 \%$, we can expect the payment index to decrease by $1 \%$; while, focusing on foreclosure cases, we can expect the payment index to decrease by $2 \%$. The policy implications of these results are rather compelling. Policy makers could reform foreclosure and bankruptcy procedures to support national economic growth, without additional burden on the public budget.
\end{abstract}

Keywords: manufacture industry, payment dynamics, institutional performance, strategic management, judicial efficiency, insolvency procedures.

JEL Classification: K12, G33.

\section{Introduction}

The risk of business failure is a relevant topic, with significant effects on the market and society. On the one hand, creditors' rights need to be defended against debtors' insolvency while, on the other hand, the national economic system needs to be supported and its reputation protected on the global market. Accordingly, the literature has focused on this topic, prompting academics and institutions to investigate bankruptcy and to propose new models that can

\footnotetext{
*Corresponding author. E-mail: roberto.ippoliti@uni-bielefeld.de
} 
predict enterprises' default with an even higher level of accuracy (Becchetti \& Sierra, 2003). The effective use of screening models can significantly reduce information asymmetries between borrowers and lenders, enhancing the efficiency of the financial intermediation process (Psillaki et al., 2010). Moreover, improvements in screening and monitoring techniques are a valuable alternative to incomplete contracts, reducing moral hazard and adverse selection problems (Stiglitz \& Weiss, 1981, 1992). However, all these efforts are fruitless without an appropriate institutional environment, able to support the enforcement of contractual obligations.

Grossman and Hart (1986), Hart and Moore (1990), and Hart (1995) suggest that contracts are incomplete if the institutional environment is not efficient, that is to say, contracts are incomplete if they cannot be fully enforced due to the poor quality of institutions. Hence, the quality of institutions might act as a disincentive for firms or industries, which require relationship-specific investments (Chakraborty, 2016). The economic implications of this hypothesis are relevant, as documented in the current literature. Levchenko (2007) and Nunn (2007) show that better institutional quality tends to increase a country's exports, while Berkowitz et al. (2006) and Ranjan and Lee (2007) highlight that countries with better contract enforcement have comparative advantages in highly differentiated final products. Focusing on a reform aimed at facilitating the speedy disposal of civil lawsuits, Chemin (2010) finds that an efficient institutional environment leads to fewer breaches of contract, encouraging investments and facilitating access to the financial market. Antràs $(2003,2005)$ provides further theoretical guidance on the micro effects of institutions, and suggests that contract enforcement can shape the business decisions and trade structures of multinational companies.

Starting from this background, our work aims to shed new light on forms of opportunistic behavior and strategic decision making that may arise in case of institutional inefficiency, causing one of the parties to adopt alternative forms of resolution and the other to increase its contractual strength. In particular, we expect a creditor to be able to collect due sums of money in case of debtor's insolvency based on how efficient courts are in enforcing credit rights. Judicial inefficiency can discourage creditors from requesting mortgage foreclosure and/or a declaration of bankruptcy, decreasing the opportunity cost of Alternative (nonjudicial) forms of Dispute Resolution (ADR), i.e., those processes that involve third parties providing conciliation and/or mediation (e.g., the State or even private facilitators) and assisting in the settlement of conflicts, but without any binding determination (Hann et al., 2019). Even more importantly, this inefficiency can increase debtors' contractual strength and, as a result, affect firm dynamics and the structure of markets. This is the main hypothesis put forward in this work and its main contribution to the current literature.

The remainder of this article is organized as follows. The first section presents an overview of the literature on judicial efficiency and its impact on economic growth and company dynamics. Then, based on the proposed background, we introduce our hypothesis regarding the expected impact of judicial inefficiency on contractual obligations. The second section illustrates the case study (i.e., the Italian manufacturing industry) and the methodology adopted to test the above hypothesis, as well as the functioning of the Italian procedures in case of insolvency (i.e., mortgage foreclosure and bankruptcy). Finally, the third section deals 
with the results of the empirical analysis, while the last section describes the conclusions of our research.

\section{Theoretical background: judicial efficiency and company dynamics}

The current literature suggests that judicial efficiency has a positive impact on economic growth (Chemin, 2009), influencing both firm dynamics (e.g., Johnson et al., 2002; Dougherty, 2014; Lichand \& Soares, 2014; Falavigna et al., 2019) and the financial markets (e.g., Djankov et al., 2008; Qian \& Strahan, 2007; Ponticelli \& Alencar, 2016). Consequently, there is a great need to improve the supply of justice, by correctly assessing the performance of the courts and of the judicial system as a whole (e.g., Falavigna et al., 2018; Silva, 2018; Mattsson \& Tidanå, 2019; Agrell et al., 2020; Ippoliti \& Tria, 2020).

According to Hayo and Voigt (2013), judicial procedures can positively affect a country's economic growth, suggesting that some procedural devices can improve a state's capacity to credibly commit to the promises contained in its laws. Moreover, Hayo and Voigt (2013) argue that, by making judicial decision more transparent and judges more accountable to the law, more trade and investments are expected to take place, which will, in turn, be reflected in higher rates of economic growth. Giacomelli and Menon (2017) show that poor contract enforcement can affect firms' incentives to grow, confirming the evidence collected by Fabbri (2010), and their results suggest that reducing the length of judicial proceedings by $10 \%$ leads to a $2 \%$ increase in the average size of local firms. Wang et al. (2014) assert that judicial quality can affect firms' exports through its efficiency in settling business contract disputes. In particular, focusing on the Chinese market, they conclude that firms in regions with better judicial quality will have a comparative advantage in exporting goods, thanks to cost saving from an efficient dispute settlement system. Looking at the Indian market, Chakraborty (2016) collects similar results, confirming that judicial quality is a significant determinant of higher firm performance in terms of both exports and domestic sales. More precisely, Chakraborty (2016) estimates that a $10 \%$ increase in judicial quality leads to a $1-2 \%$ increase in sales by local firms.

Taking the financial markets into account, Laeven and Majnoni (2005) find that judicial efficiency is one of the main drivers of interest rate spreads, implying that improvements in judicial enforcement of contracts are critical to lowering the cost of financial intermediation for households and firms. In addition, Bae and Goyal (2009) show that banks respond to poor enforceability of contracts by reducing loan amounts, shortening loan maturities, and increasing loan spreads. In a recent article, Shah et al. (2017) investigate the relation between credit rights and judicial efficiency, as well as its influence on firms' corporate leverage. Their results point to the fact that improved efficiency in enforcing these rights makes credit more readily available, due to greater loan supply. Focusing on the enforcement of insolvency cases (i.e., bankruptcy), Shah and Shah (2016) analyze the relationship between national judicial efficiency and the cash holdings of corporations. They argue that efficient judicial systems are associated with higher levels of corporate cash holdings, supporting what they call the managerial-fear hypothesis. According to this hypothesis, managers believe that improvements in judicial efficiency can increase the probability of bankruptcy and loss of their 
jobs, and they respond to this fear by hoarding extra cash as a buffer against such negative outcomes. Drawing on the seminal work by Modigliani and Miller (1958), Falavigna and Ippoliti (2018) gather similar evidence on opportunistic behavior, concluding that the higher the judicial inefficiency in enforcing creditors' rights, the higher the risks taken by managers and/or stockholders, due to the perceived lower likelihood of creditors requesting a declaration of bankruptcy. Investigating the legal consequences expected by entrepreneurs in case of insolvency, Armour and Cumming (2008) obtain, once again, similar results, showing that the relaxation of bankruptcy laws can promote entrepreneurship, since (private) failure risks and related social costs are more limited.

Against this background, we explore the efficiency of courts in enforcing creditors' rights and how this affects the performance of firms and their strategies. More precisely, considering the Italian judicial system and its laws, we investigate the relation between enforcement of creditors' rights and debtors' payments. Djankov et al. (2007) assess the enforcement of creditors' rights against defaulting debtors by constructing an aggregate index, with score between zero (poor creditors' rights) and four (strong creditors' rights). In particular, this creditor index takes four measures into account: whether secured creditors are able to seize their collateral once a reorganization petition is approved (i.e., whether the court imposes an "automatic stay" on assets); whether restrictions must be observed when a debtor files for reorganization (e.g., creditor consent), as opposed to debtors seeking unilateral protection from creditors' claims by filing for rehabilitation; whether secured creditors are paid first out of the proceeds from liquidating a bankrupt firm or whether third-party claims take priority; and whether creditors or an administrator are responsible for running the business during reorganization, rather than having the debtor continue to manage the business. This index clearly represents the creditors' difficulties in collecting the sums of money due. Another key proxy could be the time required to settle a case of insolvency, which, if particularly long, is likely to discourage creditors from taking legal action against the insolvent debtors, ultimately leading them to search for alternative approaches.

In the case of the Italian judicial system and its bankruptcy procedure, creditors may well wait for years before obtaining the enforcement of their rights (Rodano et al., 2016; Falavigna \& Ippoliti, 2018), and they can expect a low level of enforcement adaptability due to the country's legal origin (Beck \& Demirguc-Kunt, 2005) ${ }^{1}$. This result is even more significant in view of the fact that Italian businesses are not secured creditors, i.e., there are other parties that have priority in the reimbursement process (e.g., employees). In other words, considering the Italian market, there is no certainty in insolvency applications and the efficiency of the courts in enforcing bankruptcy laws may be a crucial determinant in shaping creditors' strategies. Focusing on Spain, France and the United Kingdom, García-Posada and MoraSanguinetti (2013) collect similar results, suggesting that bankruptcy law has little influence on financial distress affecting small firms, since bankruptcy procedures are costlier and longer than the main alternative judicial procedure (i.e., mortgage foreclosure). Yet, what could happen if the alternative judicial procedure for dispute resolution is also inefficient? Is an

\footnotetext{
${ }_{1}$ According to Beck and Demirguc-Kunt (2005), French legal origin countries (e.g., Italy) have low levels of enforcement adaptability, since their judiciaries are less independent from the government than in countries with common law tradition, as well as less likely to embrace jurisprudence and base judicial decisions on principles of equity.
} 
inefficient form of judicial dispute resolution (e.g., insolvency application and/or mortgage foreclosure) the best option for a creditor? Is it admissible to hypothesize that a creditor might prefer to search for alternative (non-judicial) means of dispute resolution? Moreover, is it admissible to hypothesize that a creditor might prefer to wait a few extra months to obtain the sums due (i.e., postponing the payment deadline) and avoid the related additional legal costs, rather than having to wait a few extra years for a lower and uncertain payment?

Based on these key questions, we introduce our main hypothesis: the performance of courts can shape the creditors', as well as the debtors', decision-making processes on judicial dispute resolution. On the one hand, the debtors can deliberately decide to postpone the payment deadline, substituting unsecured debt financing with supplier financing, since the institutional system is not able to guarantee the enforcement of suppliers' rights, at least not in the short run. Indeed, a solvent debtor may be unwilling to repay if the gain from insolvency is greater than the perceived cost of potential sanctions, which depends mainly on the entire set of institutional arrangements governing the credit market, as well as on its enforcement by the judiciary (Jappelli et al., 2005). On the other hand, the creditors have no other option but to search for alternative (non-judicial) means of dispute resolution, which might have unpredictable results, and to keep waiting for their money, thus increasing the debtors' contractual strength. In view of all of the above, we propose the following primary hypothesis:

$\mathrm{H}_{1}$ judicial inefficiency in enforcing credit rights can cause payment deadlines to be postponed, supporting the substitution of unsecured debt financing with supplier financing.

Current data can help us establish whether this opportunistic behavior actually exists, testing the expected positive relation between the time needed to settle a case of insolvency (i.e., mortgage foreclosure and bankruptcy) and an estimated index that is representative of payment times. If the proposed hypothesis is confirmed, the economic implications of this negative externality could be far-reaching for the whole economy, decreasing the competitiveness of the national system and triggering a cascade effect on the market. This may be even truer in the Italian market, with its characteristic structure based mostly on smallmedium enterprises (SMEs).

\section{Methodology and data}

In order to examine the proposed hypothesis, we focus on a specific case study, i.e., the Italian judiciary and manufacturing industry. On the one hand, the Italian judicial system is one of the worst in the European Union in terms of inefficiency in settling civil and penal cases (CEPEJ, 2016). On the other hand, the Italian manufacturing industry is one of the most important in Europe, with exports to third countries worth billions. This set of circumstances provides the opportunity for an interesting case study, which can shed new light on the relation between contract enforcement and firm dynamics.

Our empirical strategy relies on two key time variables: the time needed by a court to settle a judicial case of insolvency (i.e., legal period, for both mortgage foreclosure and bankruptcy) and a representative proxy for the time needed by a firm to pay a debt (i.e., payment period). Controlling for some selected external and internal variables, we test hypothesis $\mathrm{H} 1$ 
to determine whether a statistically significant positive relation between these two key time variables might exist. To do this, financial and economic information on the Italian manufacturing industry and its enterprises (our observations) is drawn from an international database (i.e., Bureau van Dijk). After thorough pre-processing of this information, data about external conditions are extracted from national databases (i.e., Ministry of Justice and Italian Institute of Statistics), and assigned to every observation as key environmental variable.

\subsection{Preprocessing phase and outlier detection}

For each enterprise, financial and economic information is extracted from the annual accounts included in the AIDA database (Source: Bureau van Dijk) ${ }^{2}$. This type of data might suffer from inaccuracies due to the digital scanning of the documentation; accordingly, preliminary checks are performed taking some simple rules for the drafting of financial statements into account. For example, we exclude firms with different values in total assets and total liabilities, negative values in debts, credits, cash, share capital, reserves, and so on.

Moreover, following the current literature (Bay et al., 2006; Schreyer et al., 2017), we apply the simple measure of the Euclidean norm of annual accounts in order to detect and remove anomalous data (Filzmoser et al., 2008). The proposed methodology may be thought of as a cluster analysis in which observations in the tails of the distribution are considered outliers and, consequently, dropped from the statistical analysis (Soltanolkotabi \& Candes, 2012). In detail, for each firm the Euclidean norm is computed as:

$$
x=\sqrt{v_{1}^{2}+\ldots+v_{J}^{2}}=\sqrt{\sum_{j=1}^{J} v_{j}^{2}},
$$

where $x$ is a vector representing the annual accounts values used in the empirical analysis of the firm under observation, and $v_{1}, \ldots, v_{j}$, are elements of vector $x$ (e.g., $x=$ (trade receivables, cash, sales,...)).

Once the norm for each firm is obtained, we look at the Median Absolute Deviation $(M A D)$ to detect and then drop the outliers (Leys et al., 2013; Huber, 1981). In addition, we perform the computation of the median $(M)$ considering three stratifications: year, industry, and size ${ }^{3}$. As suggested by Miller (1991), the rule for cutting the tails of the distribution is:

$$
M-3 M A D<x\left\langle M+3 M A D \text { or } \frac{x-M}{M A D} .\right\rangle| \pm 3| \text {. }
$$

After the application of this methodology, the number of observations is reduced by $8.65 \%$. Table 1 shows the number of observations before and after outlier detection. Note

\footnotetext{
2 The annual accounts of Italian businesses are based on the Fourth Council Directive of 25 July 1978 (78/660/EEC) and its following amending acts (see https://eur-lex.europa.eu). This financial and economic information is more detailed than that required by the International Accounting Standards (IAS), providing the opportunity for a very interesting case study.

3 This work adopts the criteria for size classification suggested by the current legislation (Recommendation 2003/361/EC and Decreto del Ministro dello Sviluppo economico del 18 aprile 2005). Accordingly, if Total Assets are under 2,000,000€/year, the firms are "Micro"; if Total Assets are between 2,000,000€/year and 10,000,000€/year, the firms are "Small"; if Total Assets are between 10,000,000€/year and 43,000,000€/year, the firms are "Medium"; and finally, if Total Assets exceed 43,000,000€/year, the firms are "Big".
} 
that the final number of observations is determined by the available information. For this reason, the numbers indicated in the empirical models (Tables 5, 6 and 7) are lower than those proposed in Table 1, which does not exclude the observations with missing values and payment time equal to zero.

Table 1. Sample size before and after outlier detection (Italy, 2014-2016)

\begin{tabular}{|l|c|c|c|c|}
\hline & 2014 & 2015 & 2016 & Total \\
\hline Before MAD & 95,151 & 99,429 & 88,362 & 282,942 \\
\hline After MAD & 86,529 & 90,501 & 81,439 & 258,469 \\
\hline
\end{tabular}

\subsection{Payment times}

In line with the main goal of the article, the key variable in our analysis is the time needed by companies to pay off their debts. Since annual accounts only report economic flows and stocks, this information is not directly available and has to be estimated by means of indexes usually adopted in this sort of analysis. The current economic literature suggests using the Cash Conversion Cycle (CCC) indexes, which prove useful in estimating the duration of the whole production period, starting from the purchase of raw materials to the cashing of revenues from sales (Wang, 2019). In particular, we focus on a specific type of CCC: the number of days needed to repay operating debts, considering the relationship between such operating debts and operating costs in a year (Hiller et al., 2013; Fraquelli et al., 2002; Enqvist et al., 2014; Jose et al., 1996).

Let $v_{1}$ be the total amount payable to suppliers, $v_{2}$ the cost of raw materials, consumables, and goods, $v_{3}$ the cost of services, and $v_{4}$ the cost of use of third-party assets. The payment index is estimated as follows:

$$
\text { Payment time }=\frac{v_{1}}{\frac{v_{2}+v_{3}+v_{4}}{360}}=\frac{v_{1}}{v_{2}+v_{3}+v_{4}} \times 360 .
$$

The result is multiplied by 360 , as a business usually runs operations for about 360 days a year. In this way, the payment index is estimated in days as unit of measurement, representing a proxy for the time needed to repay operating debts. According to the proposed approach, this index is the ratio between a stock variable (extracted from balance sheets) and the sum of flow accounts (extracted from income statements). Specifically, in the denominator, the total cost borne during the year is divided by the number of operating days (360), representing the amount of cost per day (€/days). The numerator refers to the total amount payable to suppliers at the end of the year, which does not represent the value of debt contracted during the year but the amount of debt still to be covered $(€)$. In light of the previous discussion, although it does not correspond to the real number of days of delay, the suggested index can be regarded as a proxy for delay in paying operating payables. Moreover, this index may represent varying degrees of reliance on debt financing, i.e., the results of the empirical analysis may be interpreted as indicating that debtors rely more on debt to finance operating costs when judicial enforcement is weaker. 
Table 2 presents some preliminary descriptive statistics, showing the payment index by geographical macro areas (NUTS1). It emerges from the results that the estimated time needed to repay operating debts increases dramatically moving from the North to the South of Italy.

Table 2. Average payment index by geographical macro areas. Analysis of the whole manufacturing industry (i.e., sample of observations: after MAD) - Italy, 2014-2016

\begin{tabular}{|l|c|c|c|}
\hline Geographical macro area & 2014 & 2015 & 2016 \\
\hline North West & 188 & 186 & 169 \\
\hline North East & 178 & 180 & 165 \\
\hline Center & 190 & 190 & 162 \\
\hline South & 255 & 249 & 238 \\
\hline Islands & 276 & 282 & 254 \\
\hline
\end{tabular}

This estimated payment index is the dependent variable of the empirical analysis in this work. Based on the proposed hypothesis, H1, we can expect a positive relation between this estimation (i.e., the time needed to repay an operating debt) and judicial performance (i.e., the time needed to settle a judicial dispute in case of insolvency).

\subsection{Legal times}

According to the Italian law, there are two formal procedures to settle an insolvency case (Stanghellini, 2008; Rodano et al., 2016). The creditors can either initiate a process of mortgage foreclosure (i.e., esecuzione forzata), which can target the debtors' movables or real estate, or apply to certify the debtor's insolvency (i.e., istanza di fallimento); after this preliminary step, the court will enforce their credit rights through a bankruptcy procedure (i.e., fallimento $)^{4}$. Moreover, the debtor can apply for an arrangement with creditors through the mediation of the court (i.e., concordato preventivo). Obviously, in the latter case, the creditors cannot expect to fully recover the amounts due, but the defaulting debtor may be expected to cooperate.

Under the Italian law, all creditors can engage in a mortgage foreclosure procedure, that is to say, all secured and unsecured credits can be enforced by courts through mortgage foreclosure of debtors' goods (i.e., movable and/or real estate). The main difference between secured and unsecured credits revolves around the goods involved in the insolvency procedure. In the former situation, there is a specific good that represents the collateral in case of insolvency with respect to that specific secured credit, which cannot be involved by other creditors in other insolvency procedures (i.e., there is an exclusive right to use that good as collateral for a single secured credit). In the latter situation, there are no specific guarantees for unsecured credits, i.e., all the remaining debtors' goods that do not represent a collateral for a secured credit can be involved in the insolvency procedure to collect the due amount of money. In

\footnotetext{
${ }^{4}$ Note that either the debtors themselves or the prosecutors can initiate this procedure (see Legislative Decree no. 169/2007).
} 
both cases, there is a specific judicial procedure aimed at certifying the insolvency status of the debtor (e.g., an unpaid invoice), and an order of payment is then issued by the same court (i.e., Decreto Ingiuntivo di Pagamento). After 40 days, if there are no oppositions by the debtor and/or the due payment is not made, the aforementioned order is enforceable and the foreclosure procedure can start. At this point, the payment of secured credits is facilitated by the current procedure, since a foreclosure order is not necessary (i.e., Atto di Pignoramento), simplifying the bailiff's work and reducing the time needed to collect the due amount of money, since the object of the foreclosure has already been identified (i.e., the collateral).

The alternative approach to foreclosure is bankruptcy, which is largely a debtor-protective process and prevents creditors from seizing and selling the debtor's assets piecemeal, giving time to liquidate the debtor in an orderly fashion or, more commonly, sell the business as a going concern or reorganize its capital structure. Note that only the biggest companies can be involved in bankruptcy procedures. Indeed, according to current regulations, creditors can initiate bankruptcy procedures if, and only if, the debtors have assets higher than $300,000.00$ Euro, gross revenues higher than 200,000.00 Euro and total debts higher than 500,000.00 Euro. On the other hand, all insolvent debtors can be involved in mortgage foreclosure procedures. For this reason, the numbers indicated in the empirical models with bankruptcy procedures (Tables 7) are lower than those proposed in the other models (Table 5 and 6).

The current procedures prescribe that judicial competence for insolvency cases depends on the location of either the registered office or the main production facility of the insolvent business. The Italian judicial system is currently shaped around three hierarchical levels: 140 courts of first instance (i.e., Circondari Giudiziari), 25 courts of second instance for appeals against the judgments of the previous level (i.e., Corte di Appello) ${ }^{5}$; and 1 court of third instance for appeals against the judgments of the second level (i.e., Corte di Cassazione). Therefore, the creditor will apply for a declaration of insolvency or mortgage foreclosure to the competent court of first instance, taking the location of the debtor's registered office or production facility into account, and then, if necessary, present an appeal against this judgment to the competent court of second instance.

Data about the time needed to settle an insolvency case (i.e., mortgage foreclosure and bankruptcy) are available from the Italian Ministry of Justice. Referring to the Italian justice system between 2014 and 2016, and aggregating these data at the second instance level, Table 3 clearly highlights inefficiencies in the current insolvency procedures, as well as the heterogeneity existing among macro areas (Jappelli et al., 2005). Considering mortgage foreclosure, the statistics are disaggregated according to the debtors' assets (movable or real estate).

According to our data, the time needed for the procedure to enforce outstanding credits (i.e., bankruptcy) is on average between 2,000 days (North of Italy) and 4,000 days (South of Italy). By looking at the data, the readers can easily understand the issue at hand. In the South of Italy, considering mortgage foreclosure, creditors have to wait on average between around 1 year (movable) and 7 years (real estate), while, taking bankruptcy into account, the waiting time is on average more than 10 years, and the creditors have no guarantee that

\footnotetext{
${ }^{5}$ Every court of second instance groups together several courts of first instance and is competent for appeals against first instance judgments.
} 
Table 3. Average time needed to settle an insolvency case according to judicial procedures (expressed in days) - Italy, 2014-2016

\begin{tabular}{|l|c|c|c|}
\hline $\begin{array}{c}\text { Judicial district } \\
\text { of second instance }\end{array}$ & $\begin{array}{c}\text { Mortgage foreclosure } \\
\text { (movable) }\end{array}$ & $\begin{array}{c}\text { Mortgage foreclosure } \\
\text { (real estate) }\end{array}$ & Bankruptcy \\
\hline North West & 170 & 1058 & 2476 \\
\hline North East & 155 & 885 & 2029 \\
\hline Center & 271 & 1384 & 2820 \\
\hline South & 308 & 2238 & 3852 \\
\hline Islands & 305 & 2495 & 4476 \\
\hline
\end{tabular}

they will actually receive the sums due. This exceptionally long waiting time may force the creditors to search for alternative forms of dispute resolution, avoiding the judicial insolvency process, in the hope that the debtors will eventually pay. At the same time, judicial inefficiency may represent an opportunity for the debtors to extend payment deadlines without restraint, substituting unsecured debt financing with supplier financing. These opportunistic behaviors can be considered a negative externality that is generated by the inefficiency of the enforcement system, with relevant adverse spillover effects on the market.

The time needed to settle a case has been extensively used by academics and is a valid measure of judicial performance (e.g., Christensen \& Szmer, 2012; Di Vita, 2010; Mitsopoulos \& Pelagidis, 2007). Accordingly, we adopt the time needed to settle a bankruptcy case as the key explanatory variable in the empirical investigation of this work. This time represents the expected delay in enforcing credit rights by the competent court, which can affect creditors' decision making and debtors' opportunistic behavior in financing strategies.

Note that there are also other measures of credit rights enforcement, such as the one proposed by Djankov et al. (2007) and described in the second section. Their paper investigates cross-country determinants of private credit, using data on legal creditor rights and private and public credit registries in 129 countries and estimating a creditor's rights index based on four powers of secured lenders in bankruptcy. Nevertheless, in our case study, we focus only on Italy, a single judicial system with the same insolvency law and the same regulations, i.e., the same powers of secured lenders in bankruptcy. Within the judicial system under investigation, the only element of heterogeneity is the courts' expected ability to enforce credit rights, which we estimate by adopting the time needed to settle these cases as our main measure of judicial efficiency.

\subsection{Empirical strategy}

Several multiple linear regression models are used to test the proposed hypothesis about the Italian manufacturing industry (between 2014 and 2016), adopting a pooled sample of observations. Moreover, we present the same model adopting panel data - although the dataset is rather unbalanced - and the whole sample of observations (i.e., with outliers). These are robust checks aimed at supporting causality in our key relation between judicial performance and payment dynamics. 
The dependent variable of these models is the payment index, i.e., the estimated time needed to pay a debt by manufacturing companies (i.e., our observations), controlling for several external and internal variables. The external variables include:

- time needed to settle an insolvency case by the competent court where the firm is located (considering both bankruptcy and mortgage foreclosure in different models), which is the environmental (judicial) variable of interest;

- geographical macro areas (NUTS 1) where the firms are located, which are dummy control variables introduced in the model to account for different social and cultural environments and their heterogeneities;

- years of annual accounts (i.e., 2014, 2015, or 2016), which are dummy control variables proposed to capture market trends and macroeconomic fluctuations.

The internal variables are:

- NACE codes at level 1, which are dummy control variables introduced to represent the economic activities of the observations;

- working capital (expressed in thousands of euros), which is a flow representing the operating liquidity available to a firm, calculated as the difference between current assets and current liabilities;

- legal forms, which are dummy control variables referring to whether the observations are general partnerships (i.e., S.N.C.), private limited companies (i.e., S.R.L.) or public limited companies (i.e., S.P.A.);

- specific features of companies and their ability to innovate, i.e., dummy control variables indicating whether a company is an "innovative start-up" or an "innovative small medium enterprise".

The analysis of working capital is relevant because it represents firms' self-financing (Shubita, 2019; Prasad et al., 2019; Gill et al., 2019). Positive values represent the financial solvency of firms in the short term, while negative results mean that some assets are financed by current liabilities. Table 4 shows some descriptive statistics of the dependent and independent variables.

Table 4. Descriptive statistic of the adopted variables. Analysis of the whole manufacturing industry (i.e., sample of observations: after MAD and payment index > 0) - Italy, 2014-2016

\begin{tabular}{|l|c|c|c|c|c|}
\hline \multicolumn{1}{|c|}{ Variable } & Obs & Mean & Std. Dev. & Min & Max \\
\hline Payment index $\psi$ & 252116 & 4.415 & 1.542 & 0.000 & 10.351 \\
\hline Working capital & 252116 & -145.906 & 520.599 & -2482.154 & 999.000 \\
\hline General partnership & 252115 & 0.001 & 0.023 & 0.000 & 1.000 \\
\hline Public limited company & 252115 & 0.087 & 0.282 & 0.000 & 1.000 \\
\hline Private limited company & 252115 & 0.887 & 0.317 & 0.000 & 1.000 \\
\hline Innovative start-up company & 252116 & 0.002 & 0.049 & 0.000 & 1.000 \\
\hline Innovative small business & 252116 & 0.002 & 0.042 & 0.000 & 1.000 \\
\hline Mortgage foreclosure (movable) $\psi$ & 252116 & 5.304 & 0.426 & 3.804 & 7.021 \\
\hline Mortgage foreclosure (real estate) $\psi$ & 252116 & 7.116 & 0.334 & 6.041 & 8.482 \\
\hline Bankruptcy time $\psi$ & 252116 & 7.652 & 0.466 & 4.875 & 8.889 \\
\hline North West & 252116 & 0.363 & 0.481 & 0.000 & 1.000 \\
\hline
\end{tabular}


End of Table 4

\begin{tabular}{|l|c|c|c|c|c|}
\hline \multicolumn{1}{|c|}{ Variable } & Obs & Mean & Std. Dev. & Min & Max \\
\hline North East & 252116 & 0.290 & 0.454 & 0.000 & 1.000 \\
\hline Center & 252116 & 0.186 & 0.389 & 0.000 & 1.000 \\
\hline South & 252116 & 0.126 & 0.332 & 0.000 & 1.000 \\
\hline Islands & 252116 & 0.036 & 0.186 & 0.000 & 1.000 \\
\hline 2014 & 252116 & 0.335 & 0.472 & 0.000 & 1.000 \\
\hline 2015 & 252116 & 0.351 & 0.477 & 0.000 & 1.000 \\
\hline 2016 & 252116 & 0.313 & 0.464 & 0.000 & 1.000 \\
\hline
\end{tabular}

Note: $\psi$ logarithmic transformation.

The analysis starts with a basic model in which only the external variables are considered (Model 1). Then, the internal variables of the observations are added step by step: NACE codes at level 1 (Model 2), working capital (Model 3), legal form (Model 4), and specific features of the companies (Model 5). Note that we propose three distinct analyses, respectively considering mortgage foreclosure (both movable and real estate) and bankruptcy. Obviously, taking bankruptcy into account, only the firms that meet the required criteria set by current procedures are considered in our discussion. Finally, in order to collect more robust results, Model 5 is implemented for each analysis but with panel data and considering the whole sample of observations (i.e., with outliers).

\section{Results}

Following the proposed empirical strategy, adopting a pooled sample of observations, we implement several multiple regression models to test hypotheses $\mathrm{H}_{1}$. In detail, Tables 5 and 6 look at mortgage foreclosure, focusing respectively on movable (Table 5) and real estate (Table 6), while Table 7 considers bankruptcy as insolvency procedure.

All the models are statistically significant, i.e. at least one of the predictors' regression coefficients is not equal to zero (i.e., F statistic test with p value $<0.01$ ). As for the final model, R-squared is equal to 0.065 in Table 5 and Table 6 (i.e., considering the whole population of observations and mortgage foreclosure), while in Table 7 it is equal to 0.226 (i.e., considering only the biggest firms and bankruptcy). Therefore, in terms of the micro analysis, between 7 and $23 \%$ of the variance can be explained by the variability of the independent variables. Lastly, the robust checks performed confirm these significant results.

Taking diagnostic into account, the proposed models are tested through the pairwise correlation between independent variables and the Variance Inflation Factor (VIF). In both cases, the results collected are acceptable. Note that the dummy variables "South", "NACE code 10 - Manufacture of food products", "General partnership", and "2014" are the ones against which the model is assessed and the effect is within the constant, i.e. the dummy variables are equal to zero by construction. Moreover, it can be seen that the number of observations varies depending on the firms that can be involved in the selected insolvency procedures. 


\subsection{Discussion}

Our analysis yields rather interesting results, especially considering the key explanatory variable (i.e., judicial efficiency). All the models show a statistically significant positive coefficient for the time needed to settle an insolvency case (i.e., p-value $<0.01$ ). In other words, ceteris paribus, we cannot reject hypothesis $\mathrm{H}_{1}$ that judicial inefficiency in enforcing current laws can cause payment deadlines to be postponed, increasing the debtors' contractual strength. The longer the time needed to settle a case (i.e., the courts' ability to enforce credit rights is more limited), the higher the payment index (i.e., the debtors are able to delay payments further and further, substituting unsecured debt financing with supplier financing). Accordingly, the debtors rely more on debt to finance operating costs when judicial enforcement is weaker, since the perceived expectation of credit rights enforcement by creditors is lower. More precisely, considering Model 5, if the time needed to settle a bankruptcy case decreases by $25 \%$, we can expect the payment index to decrease by $1 \%$; in addition, if the time needed to settle a mortgage foreclosure case decreases by the same percentage, we can expect the payment index to decrease by $2 \%$. These results are confirmed by several robustness checks (i.e., the same regression models with all explanatory variables but considering a panel sample and the whole population of observations), further supporting the causality relation between judicial enforcement of credit rights and payment dynamics.

Table 5. Multiple regression models, pooled sample with robust standard errors. Analysis of the manufacturing industry without outliers (i.e., sample of observations after MAD and payment index $>0$ ), considering mortgage foreclosure (movable) - Italy, 2014-2016

\begin{tabular}{|c|c|c|c|c|c|}
\hline & (Model 1) & (Model 2) & (Model 3) & (Model 4) & (Model 5) \\
\hline VARIABLES & $\begin{array}{l}\text { Payment } \\
\text { index } \psi\end{array}$ & $\begin{array}{l}\text { Payment } \\
\text { index } \psi\end{array}$ & $\begin{array}{l}\text { Payment } \\
\text { index } \psi\end{array}$ & $\begin{array}{l}\text { Payment } \\
\text { index } \psi\end{array}$ & $\begin{array}{l}\text { Payment } \\
\text { index } \psi\end{array}$ \\
\hline \multirow{2}{*}{$\begin{array}{l}\text { Mortgage } \\
\text { foreclosure } \\
\text { (movable) } \psi\end{array}$} & $0.0728^{\star * *}$ & $0.0722^{* * *}$ & $0.0650^{* * *}$ & $0.0660^{* * *}$ & $0.0661^{* * *}$ \\
\hline & $(0.00898)$ & $(0.00900)$ & $(0.00878)$ & $(0.00875)$ & $(0.00875)$ \\
\hline \multirow{2}{*}{2015} & $-0.0163^{\star *}$ & $-0.0161^{\star *}$ & $-0.0133^{\star}$ & $-0.0147^{\star \star}$ & $-0.0154^{\star *}$ \\
\hline & $(0.00744)$ & $(0.00743)$ & $(0.00730)$ & $(0.00728)$ & $(0.00728)$ \\
\hline \multirow{2}{*}{2016} & $-0.251^{\star * *}$ & $-0.250^{\star * \star}$ & $-0.246^{\star \star \star}$ & $-0.244^{\star * \star}$ & $-0.245^{\star * \star}$ \\
\hline & $(0.00798)$ & $(0.00798)$ & $(0.00778)$ & $(0.00776)$ & $(0.00776)$ \\
\hline \multirow{2}{*}{ North West } & $-0.340^{* * *}$ & $-0.333^{* * *}$ & $-0.378^{\star \star \star}$ & $-0.355^{\star \star \star}$ & $-0.354^{\star * *}$ \\
\hline & $(0.0111)$ & $(0.0113)$ & $(0.0112)$ & $(0.0112)$ & $(0.0112)$ \\
\hline \multirow{2}{*}{ North East } & $-0.383^{* * *}$ & $-0.380^{* * *}$ & $-0.436^{* * *}$ & $-0.416^{* * *}$ & $-0.416^{\star \star \star}$ \\
\hline & $(0.0120)$ & $(0.0121)$ & $(0.0119)$ & $(0.0119)$ & $(0.0119)$ \\
\hline \multirow{2}{*}{ Center } & $-0.361^{\star \star \star}$ & $-0.350^{* * *}$ & $-0.353^{* * *}$ & $-0.341^{\star \star *}$ & $-0.341^{\star \star \star}$ \\
\hline & $(0.0114)$ & $(0.0115)$ & $(0.0113)$ & $(0.0113)$ & $(0.0113)$ \\
\hline \multirow{2}{*}{ Islands } & $0.142^{\star * *}$ & $0.131^{* * *}$ & $0.135^{* * *}$ & $0.130^{\star * *}$ & $0.130^{* * *}$ \\
\hline & $(0.0178)$ & $(0.0178)$ & $(0.0178)$ & $(0.0178)$ & $(0.0178)$ \\
\hline \multirow{2}{*}{ Working capital } & & & $-0.000620^{\star * *}$ & $-0.000699^{* * *}$ & $-0.000700^{* * *}$ \\
\hline & & & $(6.14 \mathrm{e}-06)$ & $(6.38 \mathrm{e}-06)$ & $(6.38 \mathrm{e}-06)$ \\
\hline
\end{tabular}


End of Table 5

\begin{tabular}{|c|c|c|c|c|c|}
\hline & (Model 1) & (Model 2) & (Model 3) & (Model 4) & (Model 5) \\
\hline VARIABLES & $\begin{array}{l}\text { Payment } \\
\text { index } \psi\end{array}$ & $\begin{array}{l}\text { Payment } \\
\text { index } \psi\end{array}$ & $\begin{array}{l}\text { Payment } \\
\text { index } \psi\end{array}$ & $\begin{array}{l}\text { Payment } \\
\text { index } \psi\end{array}$ & $\begin{array}{c}\text { Payment } \\
\text { index } \psi\end{array}$ \\
\hline \multirow{2}{*}{$\begin{array}{l}\text { Private limited } \\
\text { company }\end{array}$} & & & & $-0.0701^{\star * *}$ & $-0.0705^{\star * \star x}$ \\
\hline & & & & $(0.0185)$ & $(0.0185)$ \\
\hline \multirow{2}{*}{$\begin{array}{l}\text { Public limited } \\
\text { company }\end{array}$} & & & & $-0.507^{\star * *}$ & $-0.507^{\star \star *}$ \\
\hline & & & & $(0.0225)$ & $(0.0225)$ \\
\hline \multirow{2}{*}{$\begin{array}{l}\text { Innovative start- } \\
\text { up company }\end{array}$} & & & & & $0.432^{\star * *}$ \\
\hline & & & & & $(0.0552)$ \\
\hline \multirow{2}{*}{$\begin{array}{l}\text { Innovative small } \\
\text { business }\end{array}$} & & & & & 0.0195 \\
\hline & & & & & $(0.0824)$ \\
\hline \multirow{2}{*}{ Constant } & $4.409^{\star * *}$ & $4.420^{\star * \star}$ & $4.390^{* * *}$ & $4.468^{\star * *}$ & $4.467^{\star * *}$ \\
\hline & $(0.0513)$ & $(0.0524)$ & $(0.0511)$ & $(0.0534)$ & $(0.0534)$ \\
\hline Observations & 252,116 & 252,116 & 252,116 & 252,115 & 252,115 \\
\hline R-squared & 0.016 & 0.017 & 0.060 & 0.065 & 0.065 \\
\hline $\begin{array}{l}\text { NACE codes at } \\
\text { level } 1 \text { (FE) }\end{array}$ & No & Yes & Yes & Yes & Yes \\
\hline
\end{tabular}

Note: ${ }^{\star * *} \mathrm{p}<0.01,{ }^{* *} \mathrm{p}<0.05,{ }^{\star} \mathrm{p}<0.1$.

Table 6. Multiple regression models, pooled sample with robust standard errors. Analysis of the manufacturing industry without outliers (i.e., sample of observations after MAD and payment index $>0$ ), considering mortgage foreclosure (real estate) - Italy, 2014-2016

\begin{tabular}{|c|c|c|c|c|c|}
\hline & (Model 1) & (Model 2) & (Model 3) & (Model 4) & (Model 5) \\
\hline VARIABLES & $\begin{array}{l}\text { Payment } \\
\text { index } \psi\end{array}$ & $\begin{array}{l}\text { Payment } \\
\text { index } \psi\end{array}$ & $\begin{array}{l}\text { Payment } \\
\text { index } \psi\end{array}$ & $\begin{array}{l}\text { Payment } \\
\text { index } \psi\end{array}$ & $\begin{array}{c}\text { Payment } \\
\text { index } \psi\end{array}$ \\
\hline \multirow{2}{*}{$\begin{array}{l}\text { Mortgage } \\
\text { foreclosure (real } \\
\text { estate) } \psi\end{array}$} & $0.0837^{\star * *}$ & $0.0878^{\star * *}$ & $0.0723^{\star * *}$ & $0.0691^{\star * *}$ & $0.0697^{\star * *}$ \\
\hline & $(0.0139)$ & $(0.0139)$ & $(0.0136)$ & $(0.0136)$ & $(0.0136)$ \\
\hline \multirow{2}{*}{2015} & $-0.0145^{\star}$ & $-0.0151^{\star *}$ & -0.0113 & -0.0119 & $-0.0127^{\star}$ \\
\hline & $(0.00755)$ & $(0.00754)$ & $(0.00742)$ & $(0.00740)$ & $(0.00740)$ \\
\hline \multirow{2}{*}{2016} & $-0.257^{\star * *}$ & $-0.258^{\star * *}$ & $-0.251^{\star * *}$ & $-0.248^{* * *}$ & $-0.249^{* * *}$ \\
\hline & $(0.00862)$ & $(0.00862)$ & $(0.00842)$ & $(0.00840)$ & $(0.00840)$ \\
\hline \multirow{2}{*}{ North West } & $-0.337^{\star * *}$ & $-0.328^{* * *}$ & $-0.378^{\star * *}$ & $-0.357^{\star * *}$ & $-0.356^{* * *}$ \\
\hline & $(0.0121)$ & $(0.0123)$ & $(0.0121)$ & $(0.0121)$ & $(0.0121)$ \\
\hline \multirow{2}{*}{ North East } & $-0.386^{* * *}$ & $-0.381^{* * *}$ & $-0.441^{\star * *}$ & $-0.423^{* * *}$ & $-0.422^{* * *}$ \\
\hline & $(0.0127)$ & $(0.0128)$ & $(0.0126)$ & $(0.0126)$ & $(0.0126)$ \\
\hline \multirow{2}{*}{ Center } & $-0.358^{\star * *}$ & $-0.345^{\star * *}$ & $-0.350^{* * *}$ & $-0.340^{* * *}$ & $-0.339^{* * *}$ \\
\hline & $(0.0117)$ & $(0.0118)$ & $(0.0116)$ & $(0.0116)$ & $(0.0116)$ \\
\hline \multirow{2}{*}{ Islands } & $0.102^{\star * \star}$ & $0.0897^{* * *}$ & $0.0999^{* * *}$ & $0.0959^{* * *}$ & $0.0959^{* * *}$ \\
\hline & $(0.0184)$ & $(0.0185)$ & $(0.0184)$ & $(0.0184)$ & $(0.0184)$ \\
\hline
\end{tabular}


End of Table 6

\begin{tabular}{|c|c|c|c|c|c|}
\hline & (Model 1) & (Model 2) & (Model 3) & (Model 4) & (Model 5) \\
\hline VARIABLES & $\begin{array}{l}\text { Payment } \\
\text { index } \psi\end{array}$ & $\begin{array}{l}\text { Payment } \\
\text { index } \psi\end{array}$ & $\begin{array}{l}\text { Payment } \\
\text { index } \psi\end{array}$ & $\begin{array}{l}\text { Payment } \\
\text { index } \psi\end{array}$ & $\begin{array}{l}\text { Payment } \\
\text { index } \psi\end{array}$ \\
\hline \multirow{2}{*}{ Working capital } & & & $-0.000620^{* * *}$ & $-0.000699^{* * *}$ & $-0.000700^{* * *}$ \\
\hline & & & $(6.14 \mathrm{e}-06)$ & $(6.38 \mathrm{e}-06)$ & $(6.38 \mathrm{e}-06)$ \\
\hline \multirow{2}{*}{$\begin{array}{l}\text { Private limited } \\
\text { company }\end{array}$} & & & & $-0.0699^{\star * *}$ & $-0.0703^{* * *}$ \\
\hline & & & & $(0.0185)$ & $(0.0185)$ \\
\hline \multirow{2}{*}{$\begin{array}{l}\text { Public limited } \\
\text { company }\end{array}$} & & & & $-0.507^{\star * *}$ & $-0.506^{\star * *}$ \\
\hline & & & & $(0.0225)$ & $(0.0225)$ \\
\hline \multirow{2}{*}{$\begin{array}{l}\text { Innovative start- } \\
\text { up company }\end{array}$} & & & & & $0.434^{* * *}$ \\
\hline & & & & & $(0.0552)$ \\
\hline \multirow{2}{*}{$\begin{array}{l}\text { Innovative small } \\
\text { business }\end{array}$} & & & & & 0.0180 \\
\hline & & & & & $(0.0824)$ \\
\hline \multirow{2}{*}{ Constant } & $4.202^{\star \star *}$ & $4.180^{\star * *}$ & $4.223^{\star * *}$ & $4.330^{\star * *}$ & $4.325^{\star * *}$ \\
\hline & $(0.102)$ & $(0.103)$ & $(0.101)$ & $(0.102)$ & $(0.102)$ \\
\hline Observations & 252,116 & 252,116 & 252,116 & 252,115 & 252,115 \\
\hline R-squared & 0.016 & 0.017 & 0.059 & 0.065 & 0.065 \\
\hline $\begin{array}{l}\text { NACE codes at } \\
\text { level } 1 \text { (FE) }\end{array}$ & No & Yes & Yes & Yes & Yes \\
\hline
\end{tabular}

Note: ${ }^{* *} \mathrm{p}<0.01,{ }^{* *} \mathrm{p}<0.05,{ }^{*} \mathrm{p}<0.1$.

Table 7. Multiple regression models, pooled sample with robust standard errors. Analysis of the manufacturing industry without outliers (i.e., sample of observations after MAD and payment index $>0$ ), considering bankruptcy - Italy, 2014-2016

\begin{tabular}{|c|c|c|c|c|c|}
\hline & (Model 1) & (Model 2) & (Model 3) & (Model 4) & (Model 5) \\
\hline VARIABLES & $\begin{array}{l}\text { Payment } \\
\text { index } \psi\end{array}$ & $\begin{array}{l}\text { Payment } \\
\text { index } \psi\end{array}$ & $\begin{array}{l}\text { Payment } \\
\text { index } \psi\end{array}$ & $\begin{array}{l}\text { Payment } \\
\text { index } \psi\end{array}$ & $\begin{array}{c}\text { Payment } \\
\text { index } \psi\end{array}$ \\
\hline \multirow{2}{*}{$\begin{array}{l}\text { Bankruptcy } \\
\text { time } \psi\end{array}$} & $0.0406^{* * *}$ & $0.0424^{\star * *}$ & $0.0371^{* * *}$ & $0.0353^{* * *}$ & $0.0354^{* * *}$ \\
\hline & $(0.00911)$ & $(0.00914)$ & $(0.00889)$ & $(0.00888)$ & $(0.00887)$ \\
\hline \multirow{2}{*}{2015} & 0.000690 & 0.000802 & 0.00160 & 0.000251 & -0.000111 \\
\hline & $(0.00787)$ & $(0.00787)$ & $(0.00772)$ & $(0.00770)$ & $(0.00770)$ \\
\hline \multirow{2}{*}{2016} & $-0.209^{* * *}$ & $-0.208^{\star * *}$ & $-0.202^{* * *}$ & $-0.201^{\star * \star}$ & $-0.202^{* * *}$ \\
\hline & $(0.00833)$ & $(0.00833)$ & $(0.00811)$ & $(0.00809)$ & $(0.00809)$ \\
\hline \multirow{2}{*}{ North West } & $-0.335^{\star * *}$ & $-0.327^{\star * *}$ & $-0.368^{\star \star *}$ & $-0.346^{* * *}$ & $-0.345^{* * *}$ \\
\hline & $(0.0124)$ & $(0.0126)$ & $(0.0124)$ & $(0.0124)$ & $(0.0124)$ \\
\hline \multirow{2}{*}{ North East } & $-0.379^{* * *}$ & $-0.373^{\star \star \star}$ & $-0.426^{\star \star \star}$ & $-0.407^{\star \star \star}$ & $-0.407^{\star * *}$ \\
\hline & $(0.0136)$ & $(0.0138)$ & $(0.0136)$ & $(0.0135)$ & $(0.0135)$ \\
\hline \multirow{2}{*}{ Center } & $-0.359^{* * *}$ & $-0.346^{\star \star *}$ & $-0.345^{\star \star \star}$ & $-0.333^{\star \star \star}$ & $-0.333^{* * *}$ \\
\hline & $(0.0130)$ & $(0.0131)$ & $(0.0129)$ & $(0.0129)$ & $(0.0129)$ \\
\hline
\end{tabular}


End of Table 7

\begin{tabular}{|c|c|c|c|c|c|}
\hline & (Model 1) & (Model 2) & (Model 3) & (Model 4) & (Model 5) \\
\hline VARIABLES & $\begin{array}{l}\text { Payment } \\
\text { index } \psi\end{array}$ & $\begin{array}{l}\text { Payment } \\
\text { index } \psi\end{array}$ & $\begin{array}{l}\text { Payment } \\
\text { index } \psi\end{array}$ & $\begin{array}{l}\text { Payment } \\
\text { index } \psi\end{array}$ & $\begin{array}{l}\text { Payment } \\
\text { index } \psi\end{array}$ \\
\hline \multirow{2}{*}{ Islands } & $0.149^{* * *}$ & $0.138^{\star \star \star}$ & $0.142^{* * *}$ & $0.138^{\star * *}$ & $0.138^{\star * *}$ \\
\hline & $(0.0207)$ & $(0.0207)$ & $(0.0206)$ & $(0.0206)$ & $(0.0206)$ \\
\hline \multirow{2}{*}{ Working capital } & & & $-0.000625^{\star * *}$ & $-0.000704^{\star * *}$ & $-0.000704^{* * *}$ \\
\hline & & & $(6.35 \mathrm{e}-06)$ & $(6.62 \mathrm{e}-06)$ & $(6.61 \mathrm{e}-06)$ \\
\hline \multirow{2}{*}{$\begin{array}{l}\text { Private limited } \\
\text { company }\end{array}$} & & & & $-0.0399^{\star}$ & $-0.0403^{\star}$ \\
\hline & & & & $(0.0224)$ & $(0.0224)$ \\
\hline \multirow{2}{*}{$\begin{array}{l}\text { Public limited } \\
\text { company }\end{array}$} & & & & $-0.466^{\star * *}$ & $-0.466^{\star * *}$ \\
\hline & & & & $(0.0258)$ & $(0.0258)$ \\
\hline \multirow{2}{*}{$\begin{array}{l}\text { Innovative start- } \\
\text { up company }\end{array}$} & & & & & $0.432^{\star * *}$ \\
\hline & & & & & $(0.0865)$ \\
\hline \multirow{2}{*}{$\begin{array}{l}\text { Innovative small } \\
\text { business }\end{array}$} & & & & & -0.0448 \\
\hline & & & & & $(0.0915)$ \\
\hline \multirow{2}{*}{ Constant } & $4.450^{\star \star \star}$ & $4.454^{\star \star \star *}$ & $4.410^{\star * *}$ & $4.484^{\star \star \star}$ & $4.483^{\star * \star}$ \\
\hline & $(0.0750)$ & $(0.0759)$ & $(0.0739)$ & $(0.0764)$ & $(0.0764)$ \\
\hline Observations & 219,856 & 219,856 & 219,856 & 219,856 & 219,856 \\
\hline R-squared & 0.014 & 0.014 & 0.060 & 0.065 & 0.065 \\
\hline $\begin{array}{l}\text { NACE codes at } \\
\text { level } 1 \text { (FE) }\end{array}$ & No & Yes & Yes & Yes & Yes \\
\hline
\end{tabular}

Note: ${ }^{* *} \mathrm{p}<0.01,{ }^{* *} \mathrm{p}<0.05,{ }^{\star} \mathrm{p}<0.1$.

Accordingly, we cannot reject the hypothesis of a significant relation between judicial inefficiency and debtors' contractual strength, and Figure 1 validates these results even more, as it highlights the substitution of unsecured debt financing with supplier financing, depending on judicial inefficiency (i.e., bankruptcy). Taking 2016 into account and court districts as observations (adopting the number of firms as weight), the figure plots the time needed to enforce credit rights and the percentage of unsecured debt over the total amount of debt, showing a negative statistically significant relation between these two variables ( $p$-value $<0.01$ ). In other words, the higher the judicial inefficiency, the higher the substitution of alternative financing by debtors.

The other results are quite interesting, too. Examining the macro areas, we can observe that companies located in the North of Italy (i.e., North West and North East) and in the Center tend to delay payments less than those in the South of Italy (i.e., South and Islands). These statistically significant results (i.e., p-value $<0.01$ ) are coherent with the current literature on heterogeneity among Italian geographical macro-areas. As for the year variable, only 2016 is statistically significant (i.e., p-value $<0.01$ ), indicating shorter delays in that year.

Coherent results are also found for working capital. All coefficients are negative and statistically significant (i.e., p-value $<0.01$ ), suggesting that an increase in working capital means 
that firms have financial resources that they use to repay their debts. So, based on our results, if the solvability of firms increases, payment times grow shorter. In other words, companies with better working capital will be characterized by lower payment index. Finally, public limited companies are more virtuous in payments than the other legal forms (i.e., general partnership or private limited company), while being an innovative start up negatively affects the time needed to repay debts.

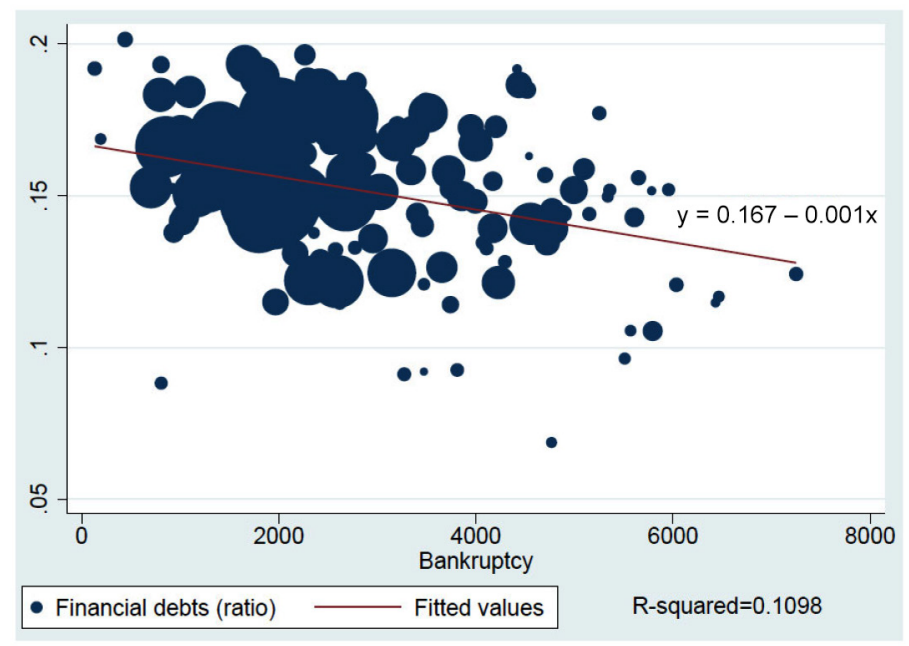

Figure 1. Substitution of unsecured debt financing with supplier financing. Analysis of the manufacturing industry without outliers (i.e., sample of observations after MAD and payment index >0), considering bankruptcy - Italy, 2016

It is worth highlighting that all the collected results are robust. Indeed, even if we increase the available information within the models, the coefficients remain statistically significant and we cannot observe relevant differences in the estimated signs. Additionally, the coherence of our coefficients is maintained even if the adopted insolvency procedures change. The next section proposes some conclusions based on the results illustrated above.

\section{Conclusions}

According to the theory of incomplete contracts, the threat of hold-up by one of the contractors depends both on the incompleteness of contracts and on costs that contractors should bear to include all possible "states of the world" (i.e., transaction costs). Moreover, the institutional environment has to safeguard contractors against opportunistic behaviors by influencing the business strategies of managers and entrepreneurs. Starting from the current knowledge, we shed new light on the key role of institutional efficiency in firm dynamics. Based on the results collected, we cannot reject our hypothesis, i.e., that judicial inefficiency negatively affects the creditors' decision to request the intervention of the courts, postponing the payment deadline and decreasing the opportunity cost of alternative (non-judicial) means of dispute resolution. Nevertheless, the enforcing power of these alternative approaches is lower, supporting the debtors' strategic behavior of substituting unsecured debt financing 
with supplier financing. This evidence may have significant implications for the whole economy - and even more so for small businesses, which represent a sizeable portion of the Italian manufacturing industry. The impact of debtors' opportunistic behaviors on the financial health of small enterprises could be dramatic, greatly reducing their solvability and, in the worst cases, driving them out of the market altogether.

Policy implications concern the opportunity to reform the organization of the courts as well as insolvency procedures, increasing judicial efficiency and, consequently, preventing hold-ups by the parties to a contract. The proposed approach is coherent with evaluations of the Italian judicial system by international institutions, such as the International Monetary Fund and the Organization for Economic Co-operation and Development, which stress the need to enhance the efficiency and effectiveness of civil procedures to ensure the smooth processing of cases in court. Hence, Italian policy makers should pursue a full reform of insolvency legislation, advancing the reorganization process that started in 2005 and $2006^{6}$. Moreover, this reform should be complemented by improvements in related laws to increase bank lending, enhancing the likelihood that claims by individual creditors against a debtor are met. At the same time, policy makers could work on the so-called informal enforcement mechanism (i.e., reputation). Indeed, when legal enforcement works poorly, firms tend invest more in connecting with others to enhance contract enforcement via the reputation mechanism; additionally, better informal enforcement improves legal enforcement because it reduces firms' incentives to bribe. Obviously, this set of elements may represent a great chance for policy makers to support national competitiveness on the global market, promoting entrepreneurship and removing barriers to entry. Even more importantly, these reforms could be implemented without diverting financial resources from other public interventions.

Despite the validity of the results presented above, our work has some limitations and there is room to improve the current analysis. Indeed, we adopt indexes to estimate average payment times and our research could be developed further when micro data on payments, as well as on alternative (non-judicial) means of dispute resolution, become available. Moreover, depending on data availability, there might be opportunities to further validate the proposed interpretation concerning the different degrees of reliance on debt financing, testing whether debtors rely more on debt to finance operating costs when judicial enforcement is weaker. Future studies may thus provide policy makers with additional support in this reform process, steering the judicial system and its services toward a new age of efficiency.

\section{Acknowledgements}

Authors acknowledge support for the publication costs by the Deutsche Forschungsgemeinschaft and the Open Access Publication Fund of Bielefeld University.

\footnotetext{
6 The 2005 reform (Legislative Decree no. 35 of 2005), inspired by Chapter 11 in US bankruptcy law, makes the renegotiation of credit contracts easier, while the 2006 reform (Law no. 5 of 2006) modifies liquidation procedures.
} 


\section{Reference}

Agrell, P. J., Mattsson, P., \& Månsson, J. (2020). Impacts on efficiency of merging the Swedish district courts. Annals of Operations Research, 288, 653-679. https://doi.org/10.1007/s10479-019-03304-0

Antràs, P. (2003). Firms, contracts, and trade structure. The Quarterly Journal of Economics, 118(4), 1375-1418. https://doi.org/10.1162/003355303322552829

Antràs, P. (2005). Incomplete contracts and the product cycle. American Economic Review, 95(4), 10541073. https://doi.org/10.1257/0002828054825600

Armour, J., \& Cumming, D. (2008). Bankruptcy law and entrepreneurship. American Law and Economics Review, 10(2), 303-350. https://doi.org/10.1093/aler/ahn008

Bae, K. H., \& Goyal, V. K. (2009). Creditor rights, enforcement, and bank loans. The Journal of Finance, 64(2), 823-860. https://doi.org/10.1111/j.1540-6261.2009.01450.x

Bay, S., Kumaraswamy, K., Anderle, M. G., Kumar, R., \& Steier, D. M. (2006, December). Large scale detection of irregularities in accounting data. In Sixth International Conference on Data Mining (ICDM'06) (pp. 75-86). Hong Kong, China. IEEE. https://doi.org/10.1109/ICDM.2006.93

Becchetti, L., \& Sierra, J. (2003). Bankruptcy risk and productive efficiency in manufacturing firms. Journal of Banking \& Finance, 27(11), 2099-2120. https://doi.org/10.1016/S0378-4266(02)00319-9

Beck, T., \& Demirguc-Kunt, A. (2005). Law and firms' access to finance. American Law and Economics Review, 7(1), 211-252. https://doi.org/10.1093/aler/ahi006

Berkowitz, D., Moenius, J., \& Pistor, K. (2006). Trade, law, and product complexity. Review of Economics and Statistics, 88(2), 363-373. https://doi.org/10.1162/rest.88.2.363

CEPEJ. (2016). Evaluation of European Judicial Systems (CEPEJ Report). European Commission for the Efficiency of Justice (CEPEJ).

Chakraborty, P. (2016). Judicial quality and regional firm performance: The case of Indian states. Journal of Comparative Economics, 44(4), 902-918. https://doi.org/10.1016/j.jce.2016.07.001

Chemin, M. (2009). The impact of the judiciary on entrepreneurship: Evaluation of Pakistan's "Access to Justice Programme". Journal of Public Economics, 93(1-2), 114-125. https://doi.org/10.1016/j.jpubeco.2008.05.005

Chemin, M. (2010). Does court speed shape economic activity? Evidence from a court reform in India. The Journal of Law, Economics, \& Organization, 28(3), 460-485. https://doi.org/10.1093/jleo/ewq014

Christensen, R. K., \& Szmer, J. (2012). Examining the efficiency of the U.S. Courts of appeals: Pathologies and prescriptions. International Review of Law and Economics, 32(1), 30-37. https://doi.org/10.1016/j.irle.2011.12.004

Di Vita, G. (2010). Production of laws and delays in court decisions. International Review of Law and Economics, 30(3), 276-281. https://doi.org/10.1016/j.irle.2010.03.006

Djankov, S., Hart, O., McLiesh, C., \& Shleifer, A. (2008). Debt enforcement around the world. Journal of Political Economy, 116(6), 1105-1149. https://doi.org/10.1086/595015

Djankov, S., McLiesh, C., \& Shleifer, A. (2007). Private credit in 129 countries. Journal of Financial Economics, 84(2), 299-329. https://doi.org/10.1016/j.jfineco.2006.03.004

Dougherty, S. M. (2014). Legal reform, contract enforcement and firm size in Mexico. Review of International Economics, 22(4), 825-844. https://doi.org/10.1111/roie.12136

Enqvist, J., Graham, M., \& Nikkinen, J. (2014). The impact of working capital management on firm profitability in different business cycles: Evidence from Finland. Research in International Business and Finance, 32, 36-49. https://doi.org/10.1016/j.ribaf.2014.03.005

Fabbri, D. (2010). Law enforcement and firm financing: Theory and evidence. Journal of the European Economic Association, 8(4), 776-816. https://doi.org/10.1111/j.1542-4774.2010.tb00540.x 
Falavigna, G., \& Ippoliti, R. (2018). Industrial spatial dynamics, financial health and bankruptcy: Evidence from Italian manufacturing industry. Economia e Politica Industriale, 45(4), 533-554. https://doi.org/10.1007/s40812-018-0102-4

Falavigna, G., Ippoliti, R., \& Manello, A. (2019). Judicial efficiency and immigrant entrepreneurs. Journal of Small Business Management, 57(2), 421-449. https://doi.org/10.1111/jsbm.12376

Falavigna, G., Ippoliti, R., \& Ramello, G. B. (2018). DEA-based Malmquist productivity indexes for understanding courts reform. Socio-Economic Planning Sciences, 62, 31-43.

https://doi.org/10.1016/j.seps.2017.07.001

Filzmoser, P., Maronna, R., \& Werner, M. (2008). Outlier identification in high dimensions. Computational Statistics \& Data Analysis, 52(3), 1694-1711. https://doi.org/10.1016/j.csda.2007.05.018

Fraquelli, G., Carelli, M. T., Capriello, A., \& Ragazzi, E. (2002). Il bilancio per i manager. Guida per interpretare $i$ fatti aziendali. CEA.

García-Posada, M., \& Mora-Sanguinetti, J. S. (2013). Are there alternatives to bankruptcy? A study of small business distress in Spain (Documentos de Trabajo N. ${ }^{\circ}$ 1315). del Banco de España.

Giacomelli, S., \& Menon, C. (2017). Does weak contract enforcement affect firm size? Evidence from the neighbour's court. Journal of Economic Geography, 17(6), 1251-1282.

Gill, A., Amiraslany, A., Obradovich, J., \& Mathur, N. (2019). Efficient working capital management, bond quality rating, and debt refinancing risk. Managerial Finance, 45(7), 869-885. https://doi.org/10.1108/MF-06-2018-0269

Grossman, S., \& Hart, O. (1986). The costs and benefits of ownership: A theory of vertical and lateral integration. Journal of Political Economy, 94(4), 691-719. https://doi.org/10.1086/261404

Hann, D., Nash, D., \& Heery, E. (2019). Workplace conflict resolution in Wales: The unexpected prevalence of alternative dispute resolution. Economic and Industrial Democracy, 40(3), 776-802. https://doi.org/10.1177/0143831X16663013

Hart, O. (1995). Firms, contracts, and financial structure. Oxford University Press. https://doi.org/10.1093/0198288816.001.0001

Hart, O., \& Moore, J. (1990). Property rights and nature of the firm. Journal of Political Economy, 98(6), 1119-1158. https://doi.org/10.1086/261729

Hayo, B., \& Voigt, S. (2013). The relevance of judicial procedure for economic growth. CESifo Economic Studies, 60(3), 490-524. https://doi.org/10.1093/cesifo/ifs044

Hillier, D., Ross, S., Westerfield, R., Jaffe, J., \& Jordan, B. (2013). Corporate finance (2 ed.). McGraw Hill.

Huber, P. J. (1981). Robust statistics. John Wiley. https://doi.org/10.1002/0471725250

Ippoliti, R., \& Tria, G. (2020). Efficiency of judicial systems: Model definition and output estimation. Journal of Applied Economics, 23(1), 385-408. https://doi.org/10.1080/15140326.2020.1776977

Jappelli, T., Pagano, M., \& Bianco, M. (2005). Courts and banks: Effects of judicial enforcement on credit markets. Journal of Money, Credit and Banking, 37(2), 223-244. https://doi.org/10.1353/mcb.2005.0021

Johnson, S., McMillan, J., \& Woodruff, C. (2002). Courts and relational contracts. Journal of Law, Economics, and Organization, 18(1), 221-277. https://doi.org/10.1093/jleo/18.1.221

Jose, M. L., Lancaster, C., \& Stevens, J. L. (1996). Corporate returns and cash conversion cycles. Journal of Economics and Finance, 20(1), 33. https://doi.org/10.1007/BF02920497

Laeven, L., \& Majnoni, G. (2005). Does judicial efficiency lower the cost of credit? Journal of Banking and Finance, 7(29), 1791-1812. https://doi.org/10.1016/j.jbankfin.2004.06.036

Levchenko, A. (2007). Institutional quality and international trade. Review of Economic Studies, 74(3), 791-819. https://doi.org/10.1111/j.1467-937X.2007.00435.x 
Leys, C., Ley, C., Klein, O., Bernard, P., \& Licata, L. (2013). Detecting outliers: Do not use standard deviation around the mean, use absolute deviation around the median. Journal of Experimental Social Psychology, 49(4), 764-766. https://doi.org/10.1016/j.jesp.2013.03.013

Lichand, G., \& Soares, R. R. (2014). Access to justice and entrepreneurship: Evidence from Brazil's special civil tribunals. The Journal of Law and Economics, 57(2), 459-499. https://doi.org/10.1086/675087

Mattsson, P., \& Tidanå, C. (2019). Potential efficiency effects of merging the Swedish district courts. Socio-Economic Planning Sciences, 67, 58-68. https://doi.org/10.1016/j.seps.2018.09.002

Miller, J. (1991). Reaction time analysis with outlier exclusion: Bias varies with sample size. The Quarterly Journal of Experimental Psychology, 43(4), 907-912. https://doi.org/10.1080/14640749108400962

Mitsopoulos, M., \& Pelagidi,s T. (2007). Does staffing affect the time to dispose cases in Greek Courts? International Review of Law and Economics, 27(2), 219-244. https://doi.org/10.1016/j.irle.2007.06.001

Modigliani, F., \& Miller, M. H. (1958). The cost of capital, corporation finance and the theory of investment. The American Economic Review, 48(3), 261-297.

Nunn, N. (2007). Relationship-specificity, incomplete contracts, and the pattern of trade. Quarterly Journal of Economics, 122(2), 569-600. https://doi.org/10.1162/qjec.122.2.569

Ponticelli, J., \& Alencar, L. S. (2016). Court enforcement, bank loans, and firm investment: evidence from a bankruptcy reform in Brazil. The Quarterly Journal of Economics, 131(3), 1365-1413. https://doi.org/10.1093/qje/qjw015

Prasad, P., Narayanasamy, S., Paul, S., Chattopadhyay, S., \& Saravanan, P. (2019). Review of literature on working capital management and future research agenda. Journal of Economic Surveys, 33(3), 827-861. https://doi.org/10.1111/joes.12299

Psillaki, M., Tsolas, I. E., \& Margaritis, D. (2010). Evaluation of credit risk based on firm performance. European Journal of Operational Research, 201(3), 873-881. https://doi.org/10.1016/j.ejor.2009.03.032

Qian, J., \& Strahan, P. E. (2007). How laws and institutions shape financial contracts: The case of bank loans. Journal of Finance, 62(6), 2803-2834. https://doi.org/10.1111/j.1540-6261.2007.01293.x

Ranjan, P., \& Lee, J. Y. (2007). Contract enforcement and international trade. Economics and Politics, 19(2), 191-218. https://doi.org/10.1111/j.1468-0343.2007.00308.x

Rodano, G., Serrano-Velarde, N., \& Tarantino, E. (2016). Bankruptcy law and bank financing. Journal of Financial Economics, 120(2), 363-382. https://doi.org/10.1016/j.jfineco.2016.01.016

Schreyer, M., Sattarov, T., Borth, D., Dengel, A., \& Reimer, B. (2017). Detection of anomalies in large scale accounting data using deep autoencoder networks. arXiv preprint arXiv:1709.05254.

Shah, A., Shah, H. A., Smith, J. M., \& Labianca, G. J. (2017). Judicial efficiency and capital structure: An international study. Journal of Corporate Finance, 44, 255-274.

https://doi.org/10.1016/j.jcorpfin.2017.03.012

Shah, H., A., \& Shah, A. (2016). The relationship between judicial efficiency and corporate cash holdings: An international study. Economic Modelling, 59, 448-462. https://doi.org/10.1016/j.econmod.2016.08.016

Shubita, M. F. (2019). The impact of working capital management on cash holdings of large and small firms: Evidence from Jordan. Investment Management \& Financial Innovations, 16(3), 76-86. https://doi.org/10.21511/imfi.16(3).2019.08

Silva, M. C. A. (2018). Output-specific inputs in DEA: An application to courts of justice in Portugal. Omega, 79, 43-53. https://doi.org/10.1016/j.omega.2017.07.006

Soltanolkotabi, M., \& Candes, E. J. (2012). A geometric analysis of subspace clustering with outliers. The Annals of Statistics, 40(4), 2195-2238. https://doi.org/10.1214/12-AOS1034 
Stanghellini, L. (2008). Le Crisi di Impresa tra Diritto ed Economia. Il Mulino, Bologna, Italy.

Stiglitz, J. E., \& Weiss, A. (1981). Credit rationing in markets with imperfect information. American Economic Review, 71(3), 912-927.

Stiglitz, J. E., \& Weiss, A. (1992). Asymmetric information in credit markets and its implications for macro-economics. Oxford Economic Papers, 44(4), 694-724. https://doi.org/10.1093/oxfordjournals.oep.a042071

Wang, B. (2019). The cash conversion cycle spread. Journal of Financial Economics, 133(2), 472-497. https://doi.org/10.1016/j.jineco.2019.02.008

Wang, Y., Wang, Y., \& Li, K. (2014). Judicial quality, contract intensity and exports: Firm-level evidence. China Economic Review, 31, 32-42. https://doi.org/10.1016/j.chieco.2014.08.002 